\title{
Empirical Evidence of IFRS Studies in Indonesia
}

\author{
Dwi Ernawati ${ }^{1}$, Y. Anni Aryani² \\ ${ }^{1}$ Magister Accounting, Faculty of Economics and Business, Universitas Sebelas Maret, Surakarta, Indonesia \\ ${ }^{2}$ Faculty of Economics and Business, Universitas Sebelas Maret, Surakarta, Indonesia \\ ${ }^{*}$ Correspondence author e-mail: dwiernawati20@gmail.com
}

\section{A R T I C LE IN F O}

\author{
A B S T R A C T
}

Article history:

Available online

Keywords:

IFRS, bibliographic study, accounting quality

DOI:

https://doi.org/10.20885/jaai.vol23. iss2.art1
This study aims to provide empirical evidence about the development of International Financial Reporting Standards (IFRS) study in Indonesia. This study analyzes thirty one IFRS articles derived from eight accredited national journals with observation period 2008-2017. We classify articles based on topics and research methods used, and then do mapping approach (charting the field). This study found financial statements quality is the most frequently researched topics. In addition, we also found research gaps on IFRS adoption and financial statement quality that were proxied by earning management and relevance. Evidently, the result of previous study is still not consistent. In addition, the previous research of IFRS adoption and the quality of financial reporting were carried out at the early phase of IFRS adoption so that it still needs to be examined how about the impact of IFRS adoption on the quality of financial reports in the next phase.

\section{Introduction}

The Global business developments require the universal accounting standards. The requirement for this standard was answered by International Accounting Standards Board (IASB) with issued the IFRS in 2001. As part of the G20 organization, Indonesia must follow the agreement to build a single set of high-quality global accounting standards in an effort to provide quality financial information in international capital market (Cahyonowati, 2012). In addition, as part of International Federation of Accountants (IFAC) requires Indonesia to use IFRS as an accounting standard (Suprihatin \& Tresnaningsih, 2013). IFRS adoption process into Indonesia Financial Reporting Standard (PSAK) has been started since 2008. Furthermore, Indonesia has adopted full IFRS as of January 1, 2012, as evidenced by the issued of SAK-IFRS.

IFRS adoption in Indonesia has a significant impact on the financial reporting process. The difference between IFRS and (Generally Accepted Accounting Principles) US GAAP standards is that IFRS implements principle based while US GAAP uses rule based. Rules based standards provide more detail rules, while principlebased standards provide less implementation guidance, therefore need more professional judgment (Agoglia et al., 2011). Based on the use of principle-based IFRS requires more detailed disclosures in the notes to the financial statement (Yaacob \& Che- Ahmad, 2012).

The previous research indicate that there are several problems in implementing IFRS. Evans et al. (2005) stated that differences in culture and language can be obstacles in the application of international accounting standards. Efferin and rudiawarni (2014) analyzed the obstacles of IFRS implementation in Indonesia from the regulators, auditors, corporate accountants, accounting learning and users of financial statements perspective. Limited resources are a problem faced by regulators. The auditor is in a dilemmatic position on the one hand the auditor holds the role of providing independent professional judgment but on the other hand the auditor is confronted with clients who request optimal service. Furthermore, loyalty to the leadership, pragmatic culture and language are obstacles faced by corporate accountants in implementing IFRS. The challenge faced in accounting learning is how to shape students' critical thinking patterns in interpreting accounting standards, so that they will be able to provide professional judgment. The last obstacle is the users of financial statements only see IFRS as a normative provision from the regulator and do not see IFRS as an effort to improve the quality of financial statements.

Full adoption of IFRS in Indonesia beginning of 2012 attracted many researchers to conduct research related to the full impact of IFRS adoption on the company's financial reporting process. The financial statements should be qualified because they are the main source of decision making. This study aims to provide empirical evidence of research relating to the adoption of IFRS in Indonesia which has been done by many researchers in 
Indonesia. This research analyzes thirty-one IFRS articles published in accredited national journals until 2017. The process of mapping of IFRS research results is done by analyzing IFRS research methods and topics that exist in Indonesia during the observation year. It is expected that this research will contribute to mapping the results of research on IFRS adoption and its impact in Indonesia, so that we are able to see the areas/topics that still required to be investigated further related to IFRS in Indonesia.

This paper is organized as follows. Section 2 provides review of the relevance literature. In section 3 we discripe the data and methodology were used in this study. We presented the empirical result and discussion in section 4 . The last section is summary and conclusions.

\section{Literature Review}

\section{IFRS Study}

The development of global business makes the companies able to operate in several countries or called multinational companies. Multinational companies require financial statements that apply globally so that businesses in various countries can be compared. In addition, business globalization also makes investors, regulators, auditor and large companies aware of the importance of global financial reporting standards (Shobriati \& Siregar, 2016). Therefore IASB developed International accounting standards in 2001 and have been adopted by 166 countries arround the world (IFRS Foundation, 2018). IFRS adoption attracts many researchers in various countries to conduct research on the impact of IFRS adoption.

Indonesia began adopting IFRS in 2012, but the process of converting the Financial Accounting Standard (SAK) to IFRS has begun since 2008 although the implementation is still voluntary. As in various countries, the adoption of IFRS in Indonesia is also an interesting topic to study as evidenced by the number of researchers who examine the impact of IFRS adoption in Indonesia. Some studies of the influence of IFRS adoption in Indonesia are: adoption IFRS and accounting quality (Evans et al., 2005; Karyada \& Irwanto, 2017; Suprihatin \& Tresnaningsih, 2013; Wulandari \& Adiati, 2015), adoption IFRS and audit fee (Cahyonowati, 2012; Kusumaningwedari \& Oktorina, 2017), adoption IFRS and cost of capital (Sanjaya \& Barus, 2017), adoption IFRS and firm value (Hendika \& Hudiwinarsih, 2014; Pranata \& Pujiati, 2015).

From the description above shows that the previous IFRS study, researchers have linked the adoption of IFRS with many variables, so that content analysis is needed which gives an overview of the results of previous IFRS research. Content analysis shows effect of IFRS adoption on some variables from several studies. Then, the results of the analysis content are mapped in a diagram. We can show research gap from the mapping.

The results of this mapping can then be used by subsequent researchers to design IFRS research in the future. According with the opinion Villas et al. (2008) which states that it is necessary to conduct bibliographic research to find out the development of a knowledge and to find a research gap. Although the literature review research on IFRS adoption has been done before, but as far as the knowledge of the author there is no previous IFRS bibliography research especially in Indonesia, therefore this research needs to be done.

\section{Bibliography Research}

Bibliographic research is a part of qualitative research. Bibliographic research is conducted by analyzing a topic based on a point of view by using scientific publications (articles, procedia, book, etc.) as analytical material. Thus, finding the high quality sources (journals) is very important in bibliographic research. Zoogah and Rigg (2014) state that there are three processes in doing bibliographic research, as follow: data collection, data preparation and data analysis. The purpose of bibliographic research is to find out the development of research on a certain topic or knowledge so that research gaps can be found (Villas et al., 2008).

Bibliographic research has been explored in previous studies Hesford et al. (2007) doing bibliographic research in management accounting using sample of 916 articles in 10 journals from 1981-2000. In this study (Hesford et al., 2007) analyzed management accounting articles with two approaches: charting the field and community analysis. Bibliographic research has also been conducted in Indonesia e.g. tax research bibliography and earning management research bibliography (Herawati \& Bandi, 2017; Suprianto \& Setiawan, 2017).

\section{Methodology}

Following Hesford et al. (2007) we use the "charting field" method. This study analyzes articles about IFRS collected from journals accredited by Indonesia Ministry of Research and Higher Education listed in 2017 and published online. This study only uses sample journals accredited by Indonesia Ministry of Research and Higher Education to ensure that the samples used have equal quality. Based on such restrictions, there are 36 (thirty six) articles from 10 (ten) national accredited journals, i.e.: Binus Bisnis Review, Jurnal Akuntansi dan Keuangan Indonesia, then abbreviated as 
JAKI, Jurnal Akuntansi Multiparadigma which then abbreviated as JAMAL, Jurnal Keuangan dan Perbankan then abbreviated as JKP, Jurnal Akuntansi dan Keuangan, then abbreviated as JAK, Jurnal Manajemen Teknologi which was then abbreviated as JMT, Jurnal Akuntansi dan Auditing Indonesia (JAAI), Journal of ETIKONOMI, Journal of Economics, Business \& Accountancy VENTURA, and The Indonesian Accounting Review later shortened by TIAR. The number of articles were found in each journal can be seen in Table 1.

Table 1. IFRS Articles on Accredited National Journal

\begin{tabular}{lc}
\hline \multicolumn{1}{c}{ Nam of Journal } & Number of Articles \\
\hline Binus Business Review & 9 \\
JAKI & 4 \\
JAMAL & 4 \\
JKP & 1 \\
JAK & 2 \\
JMT & 2 \\
JAAI & 3 \\
ETIKONOMI & 1 \\
VENTURA & 7 \\
TIAR & 4 \\
\hline & 36 \\
\hline
\end{tabular}

This study aims to describe the development of IFRS research in Indonesia, so this study only take articles that use sample companies in Indonesia as an analysis material. Based on these objectives, we exclude an article from JMT Journal, an article from the ETIKONOMI Journal, an article from JAAI Journal and two articles from the Ventura Journal. Thus, the articles are used as an analysis material in this study reduced by five articles. As a result, the total final samples used in this study are 31 articles from eight national accredited journals. The details of the articles are presented in appendix.

The observation period of this study is 2008-2017. Year 2008 chosen as the starting point year of observation because this year is early adoption of IFRS in Indonesia, where there are three PSAK effective on January $1^{\text {st }}$, 2008 i.e. PSAK 13, 16 and 30 (Suprihatin \& Tresnaningsih, 2013). This study chooses year 2017 as the final point for observation because 2017 was included in the second phase full adoption. This study divides observations in three periods that are 2008-2011 as a full pre-adoption period, 2012-2014 full adoption of the first phase and the year 2015-2017 the second phase full adoption. This classification follows the development of IFRS adoption by Indonesian Institute of Accountants (IAI) in Indonesia.

\section{Results and Discussion}

\section{Journals Share}

The selection process results 31 articles that online available. We take a bibliography of those articles covering title of the article, name of the journal, volume and number of the journal, publication year, page, name of the researcher and research institution. Table 2, shows the journal share of the IFRS article. For a decade IFRS studies have conducted in Indonesia, the most IFRS articles are found in Journal of Binus Business Review, that is $29 \%$, then Ventura 16\%, JAKI, JAMAL and TIAR 13\%, JAAI and JAK 6\% and JKP 1\%, respectively.

Table 2. Journal Share

\begin{tabular}{lcccccccc}
\hline \multirow{2}{*}{ Name of Journals } & \multicolumn{2}{c}{$2008-2017$} & \multicolumn{2}{c}{$2008-2011$} & \multicolumn{2}{c}{$2012-2014$} & \multicolumn{2}{c}{$2015-2017$} \\
\cline { 2 - 9 } & Sum & $\%$ & Sum & $\%$ & Sum & $\%$ & Sum & $\%$ \\
\hline Binus Bisnis Review & 9 & $29 \%$ & 2 & $67 \%$ & 7 & $41 \%$ & 0 & $0 \%$ \\
JAAI & 2 & $6 \%$ & 0 & $0 \%$ & 2 & $12 \%$ & 0 & $0 \%$ \\
JAK & 2 & $6 \%$ & 0 & $0 \%$ & 1 & $6 \%$ & 1 & $9 \%$ \\
JAKI & 4 & $13 \%$ & 0 & $0 \%$ & 2 & $12 \%$ & 2 & $18 \%$ \\
JKP & 1 & $3 \%$ & 0 & $0 \%$ & 0 & $0 \%$ & 1 & $9 \%$ \\
JAMAL & 4 & $13 \%$ & 0 & $0 \%$ & 1 & $6 \%$ & 3 & $27 \%$ \\
VENTURA & 5 & $16 \%$ & 1 & $33 \%$ & 3 & $18 \%$ & 1 & $9 \%$ \\
TIAR & 4 & $13 \%$ & 0 & $0 \%$ & 1 & $6 \%$ & 3 & $27 \%$ \\
\hline
\end{tabular}


Based on the data presented in Table 2, there is an increase number of IFRS articles from the pre-full adoption period to the first-full adoption period from three articles rise to 17 articles, an increase of nearly 600 percent. However, there are decrease numbers of IFRS articles from the first-phase to the second phase i.e. from 17 articles to 11 articles, decreasing articles amount by 35 percent. The increase numbers of the articles in the firstphase may be because the IFRS adoption is a new phenomenon in the field of accounting so that many researchers are interested to examine the impact of IFRS implementation in Indonesia. It means the implementation of IFRS in Indonesia becomes a hot topic for researchers.

\section{Article Classification}

Following (Hesford et al., 2007), we classified articles based on topics and methods.

\section{Topic}

In this study, we classified the topics into six groups i.e.: quality of financial statements, investors and capital markets, fair value, audit, corporate performance and others. This classification is based on the most widely used topic analysis results in articles used as samples in this study. Table 3 shows that the topics are dominated by the quality of financial statements, 45\% (e.g. Margaretta \& Soepriyanto, 2012; Suprihatin \& Tresnaningsih, 2013), IFRS articles on investors and capital markets are 13\% (Margaret \& Hidayat, 2016; Putri et al., 2012; Sanjaya \& Barus, 2017; Sun et al., 2014), IFRS articles with fair value topic are 13\% (Ariyanto et al., 2012; Kurniawati, 2013; Novianti, 2011; Sukendar, 2012) IFRS articles with audit topics are 6\% (Cahyonowati, 2012; Shonhadji, 2012), the company performance topics are 6\% (Pranata \& Pujiati, 2015; Sari \& Murni, 2016) and IFRS articles with other topics are 14\% (Efferin \& Rudiawarni, 2014; Panggabean, 2010; Sukendar, 2014). Two IFRS research topics that have increased from first to second phase adoption are topics quality of financial statements and company performance. The quality of financial statements rise from $17 \%$ in the first phase of adoption to $20 \%$ in the second phase of adoption. The company's performance topics rise about $6 \%$ in the second phase of adoption period. However, three topics of IFRS research have decreased from the first phase of adoption to the second phase of adoption. Those three topics are fair value, audit and other topics. In addition, investors and capital markets topics shows constant from the first phase adoption to second phase adoption.

Table 3. Topics Classification

\begin{tabular}{|c|c|c|c|c|c|c|c|c|}
\hline Topics & 20 & $8-2017$ & & $8-2011$ & & -2014 & & -2017 \\
\hline Financial Reporting Quality & 14 & $45 \%$ & 1 & $3 \%$ & 6 & $19 \%$ & 7 & $23 \%$ \\
\hline Relevance & 7 & $23 \%$ & 1 & $3 \%$ & 3 & $10 \%$ & 3 & $10 \%$ \\
\hline Timelines & 1 & $3 \%$ & 0 & $0 \%$ & 1 & $3 \%$ & 0 & $0 \%$ \\
\hline Earning Management & 6 & $17 \%$ & 0 & $0 \%$ & 2 & $6 \%$ & 4 & $13 \%$ \\
\hline Investors and Capital Market & 4 & $13 \%$ & 0 & $0 \%$ & 2 & $6 \%$ & 2 & $6 \%$ \\
\hline Investor Perception towards non-controlling interest presentation & 1 & $3 \%$ & 0 & $0 \%$ & 0 & $0 \%$ & 1 & $3 \%$ \\
\hline Market Reaction to IFRS implementation & 1 & $3 \%$ & 0 & $0 \%$ & 1 & $3 \%$ & 0 & $0 \%$ \\
\hline Cost Equity Capital & 1 & $3 \%$ & 0 & $0 \%$ & 0 & $0 \%$ & 1 & $3 \%$ \\
\hline Investors perception toward risk management & 1 & $3 \%$ & 0 & $0 \%$ & 1 & $3 \%$ & 0 & $0 \%$ \\
\hline Fair Value & 4 & $13 \%$ & 1 & $3 \%$ & 3 & $10 \%$ & 0 & $0 \%$ \\
\hline Fair value concepts & 1 & $3 \%$ & 0 & $0 \%$ & 1 & $3 \%$ & 0 & $0 \%$ \\
\hline IAS 41 adoption & 1 & $3 \%$ & 0 & $0 \%$ & 1 & $3 \%$ & 0 & $0 \%$ \\
\hline Trends in the selection of fair value and historical cost & 1 & $3 \%$ & 0 & $0 \%$ & 1 & $3 \%$ & 0 & $0 \%$ \\
\hline Revaluation & 1 & $3 \%$ & 1 & $3 \%$ & 0 & $0 \%$ & 0 & $0 \%$ \\
\hline Audit & 2 & $6 \%$ & 0 & $0 \%$ & 2 & $6 \%$ & 0 & $0 \%$ \\
\hline Audit fee & 1 & $3 \%$ & 0 & $0 \%$ & 1 & $3 \%$ & 0 & $0 \%$ \\
\hline Auditor readiness & 1 & $3 \%$ & 0 & $0 \%$ & 1 & $3 \%$ & 0 & $0 \%$ \\
\hline Firm Performance & 2 & $6 \%$ & 0 & $0 \%$ & 0 & $0 \%$ & 2 & $6 \%$ \\
\hline Profitability & 1 & $3 \%$ & 0 & $0 \%$ & 0 & $0 \%$ & 1 & $3 \%$ \\
\hline Stock Price & 1 & $3 \%$ & 0 & $0 \%$ & 0 & $0 \%$ & 1 & $3 \%$ \\
\hline Others & 5 & $16 \%$ & 1 & $3 \%$ & 4 & $13 \%$ & 0 & $0 \%$ \\
\hline Stakeholder behavior in adoption of IFRS & 1 & $3 \%$ & 0 & $0 \%$ & 1 & $3 \%$ & 0 & $0 \%$ \\
\hline PSAK and Tax harmonization & 1 & $3 \%$ & 0 & $0 \%$ & 1 & $3 \%$ & 0 & $0 \%$ \\
\hline Curriculum & 1 & $3 \%$ & 0 & $0 \%$ & 1 & $3 \%$ & 0 & $0 \%$ \\
\hline SAK and IFRS comfromity & 1 & $3 \%$ & 1 & $3 \%$ & 0 & $0 \%$ & 0 & $0 \%$ \\
\hline IFRS adoption in Indonesia & 1 & $3 \%$ & 0 & $0 \%$ & 1 & $3 \%$ & 0 & $0 \%$ \\
\hline & 31 & $100 \%$ & 3 & $10 \%$ & 17 & $55 \%$ & 11 & $35 \%$ \\
\hline
\end{tabular}


Based on the analysis it appears that in the second phase adoption researchers are more interested to study the impact of IFRS adoption on the quality of financial statements and company performance than other topics such as auditing and fair value as evidenced by an increase the number of IFRS study on the topic quality of financial statement and company performance in the second phase adoption. In the second phase adoption researchers want to know more about the impact of the implementation IFRS rather than readiness in the implementation of IFRS.

IFRS research topics of financial statements quality consists of relevance, timeliness and earnings management topics. The most popular topics from the quality of financial statements are relevance topic that is seven articles or $23 \%$. The topic category of investors and capital markets consists of investor perceptions of noncontrolling interest presentation, market reactions to IFRS implementation, cost equity capital and investor's view of risk management. From each topic of investor and capital market the same amount is one article or 3\%. The fair value topic category consists of a fair value concept, an IAS 41 adoption plan, a trend of fair value selection and historical cost, and a revaluation. Each fair value topic category does not dominate.

Audit cost and auditor preparedness are included in the category of audit topics with the number of articles in each topic is one article. The topic category of company performance consists of one profitability topics and one stock price topic. Other topic categories consist of stakeholder behavior in IFRS adoption, harmonization of PSAK and taxes, curriculum, suitability of PSAK and IFRS, and IFRS adoption in Indonesia. The other categories is evenly distributed for each topic i.e. $3 \%$.

Based on the results of the above analysis, it can be concluded that the most popular topics related with the impementation of IFRS in Indonesia is the quality of financial statements. The numbers of IFRS study on the quality of financial statements proves that many researchers want to provide evidence about the benefits of IFRS implementation as stated by Barth (2008) that the purpose of IFRS adoption is to improve the quality of financial statement information. The IFRS influence on the quality of financial statements is also widely researched abroad (e.g Houqe et al., 2016; Jeanjean \& Stolowy, 2008; Wan Ismail et al., 2013; Zeghal et al., 2012).

\section{Research Method}

This study classifies the method used in the 31 IFRS articles into two categories. The first category of the articles is grouped into qualitative and quantitative methods. Grouping of the articles in the first category is presented in Table 4. The second category of the articles is grouped into archival, literature review, experiment and survey methods. Grouping articles in the second category is presented in Table 5 . Table 4 shows $71 \%$ of research using quantitative methods and $29 \%$ of research using qualitative methods. The most quantitative methods are used in the journal VENTURA, JAMAL and TIAR each 13\%, JAKI 10\%, Binus Business Review, JAAI, and JAK 6\% and JKP 3\%, respectively. Furthermore, the qualitative method mostly use in Binus Business Review which is seven articles or $23 \%$.

Table 4. Article Classification-Research Method Classification (1)

\begin{tabular}{|c|c|c|c|c|c|c|c|c|c|c|c|c|c|c|c|c|c|}
\hline \multirow{3}{*}{ No. } & \multirow{3}{*}{ Journal } & \multicolumn{4}{|c|}{ 2008-2017 } & \multicolumn{4}{|c|}{ 2008-2011 } & \multicolumn{4}{|c|}{ 2012-2014 } & \multicolumn{4}{|c|}{ 2015-2017 } \\
\hline & & \multicolumn{2}{|c|}{ Quantitative } & \multicolumn{2}{|c|}{ Qualitative } & \multicolumn{2}{|c|}{ Quantitative } & \multicolumn{2}{|c|}{ Qualitative } & \multicolumn{2}{|c|}{ Quantitative } & \multicolumn{2}{|c|}{ Qualitative } & \multicolumn{2}{|c|}{ Quantitative } & \multicolumn{2}{|c|}{ Qualitative } \\
\hline & & Sum & $\%$ & Sum & $\%$ & Sum & $\%$ & Sum & $\%$ & Sum & $\%$ & Sum & $\%$ & Sum & $\%$ & Sum & $\%$ \\
\hline 1 & $\begin{array}{l}\text { Binus Bisnis } \\
\text { Review }\end{array}$ & 2 & $6 \%$ & 7 & $23 \%$ & 0 & $0 \%$ & 2 & $22 \%$ & 2 & $9 \%$ & 5 & $56 \%$ & 0 & $0 \%$ & 0 & $0 \%$ \\
\hline 2 & JAKI & 3 & $10 \%$ & 1 & $3 \%$ & 0 & $0 \%$ & 0 & $0 \%$ & 2 & $9 \%$ & 0 & $0 \%$ & 2 & $9 \%$ & 0 & $0 \%$ \\
\hline 3 & JAMAL & 4 & $13 \%$ & 0 & $0 \%$ & 0 & $0 \%$ & 0 & $0 \%$ & 0 & $0 \%$ & 1 & $11 \%$ & 3 & $14 \%$ & 0 & $0 \%$ \\
\hline 4 & JKP & 1 & $3 \%$ & 0 & $0 \%$ & 0 & $0 \%$ & 0 & $0 \%$ & 0 & $0 \%$ & 0 & $0 \%$ & 1 & $5 \%$ & 0 & $0 \%$ \\
\hline 5 & JAK & 2 & $6 \%$ & 0 & $0 \%$ & 0 & $0 \%$ & 0 & $0 \%$ & 1 & $5 \%$ & 0 & $0 \%$ & 1 & $5 \%$ & 0 & $0 \%$ \\
\hline 6 & JAAI & 2 & $6 \%$ & 0 & $0 \%$ & 0 & $0 \%$ & 0 & $0 \%$ & 2 & $9 \%$ & 0 & $0 \%$ & 0 & $0 \%$ & 0 & $0 \%$ \\
\hline 7 & VENTURA & 4 & $13 \%$ & 1 & $3 \%$ & 1 & $5 \%$ & 0 & $0 \%$ & 2 & $9 \%$ & 1 & $11 \%$ & 1 & $5 \%$ & 0 & $0 \%$ \\
\hline \multirow[t]{2}{*}{8} & TIAR & 4 & $13 \%$ & 0 & $0 \%$ & 0 & $0 \%$ & 0 & $0 \%$ & 1 & $5 \%$ & 0 & $0 \%$ & 3 & $14 \%$ & 0 & $0 \%$ \\
\hline & Total & 22 & $71 \%$ & 9 & $29 \%$ & 1 & $5 \%$ & 2 & $22 \%$ & 10 & $45 \%$ & 7 & $78 \%$ & 11 & $50 \%$ & 0 & $0 \%$ \\
\hline
\end{tabular}

Table 5 shows for ten years observation of IFRS research. Archival method is the most frequently used method that reached $68 \%$, then follows by literature review method which is $16 \%$, survey $13 \%$ and experiment $3 \%$, respectively. Archival method has increased in each observation period. Experimental methods, case studies and survey increased from pre adoption to the first phase adoption, but decreased in the second phase of adoption. 
In the second phase adoption all of the IFRS research observed by the archival method, this may be due to the adoption of the second phase in year 2015. The IAI has issued SAK-IFRS so that all companies listing on the Securities Exchange must use SAK-IFRS as an accounting standard; this makes it easier for researchers to obtain secondary data. Thus the researchers in the second phase of adoption prefer to use archival method. These findings are consistent with Adhikari et al. (2002) and Dykxhoorn and Sinning (2010) that find international accounting research more inclined to empirical methodology.

Table 5. Article Classification-Research Method Classification (2)

\begin{tabular}{|c|c|c|c|c|c|c|c|c|c|}
\hline \multirow{2}{*}{ No. } & \multirow{2}{*}{ Research Method } & \multicolumn{2}{|c|}{$2008-2017$} & \multicolumn{2}{|c|}{$2008-2011$} & \multicolumn{2}{|c|}{$2012-2014$} & \multicolumn{2}{|c|}{$2015-2017$} \\
\hline & & Sum & $\%$ & Sum & $\%$ & Sum & $\%$ & Sum & $\%$ \\
\hline 1 & Archival & 21 & $68 \%$ & 2 & $6 \%$ & 8 & $26 \%$ & 11 & $35 \%$ \\
\hline 2 & Experiment & 1 & $3 \%$ & 0 & $0 \%$ & 1 & $3 \%$ & 0 & $0 \%$ \\
\hline 3 & Literatur Review & 5 & $16 \%$ & 1 & $3 \%$ & 4 & $13 \%$ & 0 & $0 \%$ \\
\hline \multirow[t]{2}{*}{4} & Survey & 4 & $13 \%$ & 0 & $0 \%$ & 4 & $13 \%$ & 0 & $0 \%$ \\
\hline & Total & 31 & $100 \%$ & 3 & $10 \%$ & 17 & $55 \%$ & 11 & $35 \%$ \\
\hline
\end{tabular}

\section{Journal Characteristics}

The tabulated results in Table 6 illustrate the topic of research based on the journal. The results show IFRS articles in JAKI $(50 \%)$, JAMAL $(100 \%)$, JAK $(100 \%)$ are dominated by topics quality of financial statements. Topics of investors and capital markets dominate in JAK (100\%). Fair value topics are more widely researched in the Binus Business Review journal, while other topics dominate in the Ventura Journal by $40 \%$.

Table 6. Journal Characteristics-Topic Based Journal

\begin{tabular}{|c|c|c|c|c|c|c|c|c|c|c|c|c|c|c|c|}
\hline \multirow{3}{*}{ No } & \multirow{3}{*}{ Jurnal } & \multicolumn{14}{|c|}{ Topic } \\
\hline & & \multicolumn{2}{|c|}{$\begin{array}{l}\text { Financial } \\
\text { Reporting } \\
\text { Quality }\end{array}$} & \multicolumn{2}{|c|}{$\begin{array}{l}\text { Investors and } \\
\text { Capital Market }\end{array}$} & \multicolumn{2}{|c|}{ Fair Value } & \multicolumn{2}{|c|}{ Audit } & \multicolumn{2}{|c|}{ Performance } & \multicolumn{2}{|c|}{ Other } & \multicolumn{2}{|c|}{ Total } \\
\hline & & Sum & $\%$ & Sum & $\%$ & Sum & $\%$ & Sum & $\%$ & Sum & $\%$ & Sum & $\%$ & Sum & $\%$ \\
\hline 1 & $\begin{array}{l}\text { Binus Bisnis } \\
\text { Review }\end{array}$ & 1 & $11 \%$ & 1 & $11 \%$ & 4 & $44 \%$ & 0 & $0 \%$ & 0 & $0 \%$ & 3 & $33 \%$ & 9 & $100 \%$ \\
\hline 2 & JAKI & 2 & $50 \%$ & 1 & $25 \%$ & 0 & $0 \%$ & 0 & $0 \%$ & 0 & $0 \%$ & 1 & $25 \%$ & 4 & $100 \%$ \\
\hline 3 & JAMAL & 4 & $100 \%$ & 0 & $0 \%$ & 0 & $0 \%$ & 0 & $0 \%$ & 0 & $0 \%$ & 0 & $0 \%$ & 4 & $100 \%$ \\
\hline 4 & JKP & 0 & $0 \%$ & 1 & $100 \%$ & 0 & $0 \%$ & 0 & $0 \%$ & 0 & $0 \%$ & 0 & $0 \%$ & 1 & $100 \%$ \\
\hline 5 & JAK & 2 & $100 \%$ & 0 & $0 \%$ & 0 & $0 \%$ & 0 & $0 \%$ & 0 & $0 \%$ & 0 & $0 \%$ & 2 & $100 \%$ \\
\hline 6 & JAAI & 1 & $50 \%$ & 0 & $0 \%$ & 0 & $0 \%$ & 1 & $50 \%$ & 0 & $0 \%$ & 0 & $0 \%$ & 2 & $100 \%$ \\
\hline 7 & VENTURA & 2 & $40 \%$ & 1 & $20 \%$ & 0 & $0 \%$ & 1 & $20 \%$ & 0 & $0 \%$ & 1 & $20 \%$ & 5 & $100 \%$ \\
\hline \multirow[t]{2}{*}{8} & TIAR & 2 & $50 \%$ & 0 & $0 \%$ & 0 & $0 \%$ & 0 & $0 \%$ & 2 & $50 \%$ & 0 & $0 \%$ & 4 & $100 \%$ \\
\hline & & 14 & $45 \%$ & 4 & $13 \%$ & 4 & $13 \%$ & 2 & $6 \%$ & 2 & $6 \%$ & 5 & $16 \%$ & 31 & $100 \%$ \\
\hline
\end{tabular}

Table 7 tabulates journal characteristics based on the method used. The results of the tabulation show quantitative method dominant in JAKI (75\%), JAMAL (100\%), JKP (100\%), JAK (100\%), JAAI (100\%), VENTURA $(80 \%)$, TIAR $(100 \%)$, while the qualitative method dominates in the journal of Binus Business Review, which is 78\%. Table 8 shows the archival method dominant in JAKI (75\%), JAMAL (100\%), JKP (100\%), JAK (100\%), JAAI (100\%), VENTURA journals (40\%) and TIAR (100\%). The literature review method is mostly use in Binus Business Review journal (56\%) and the survey method is mostly use in the journal of VENTURA (40\%).

Based on the description above it can be concluded that most journals are use quantitative methods in discussing IFRS theme. The reason of this is perhaps that most research on IFRS have an objective to test the effectiveness of the application of IFRS, thus the use of quantitative methods is more appropriate. While the archival model is more widely used because some research have use secondary data. 
Table 7. Journal Characteristics-Method Based Journal (1)

\begin{tabular}{|c|c|c|c|c|c|c|c|}
\hline \multirow{3}{*}{ No. } & \multirow{3}{*}{ Jurnal } & \multicolumn{6}{|c|}{$2008-2017$} \\
\hline & & \multicolumn{2}{|c|}{ Quantitative } & \multicolumn{2}{|c|}{ Qualitative } & \multicolumn{2}{|c|}{ Total } \\
\hline & & Sum & $\%$ & Sum & $\%$ & Sum & $\%$ \\
\hline 1 & Binus Bisnis Review & 2 & $22 \%$ & 7 & $78 \%$ & 9 & $100 \%$ \\
\hline 2 & JAKI & 3 & $75 \%$ & 1 & $25 \%$ & 4 & $100 \%$ \\
\hline 3 & JAMAL & 4 & $100 \%$ & 0 & $0 \%$ & 4 & $100 \%$ \\
\hline 4 & JKP & 1 & $100 \%$ & 0 & $0 \%$ & 1 & $100 \%$ \\
\hline 5 & JAK & 2 & $100 \%$ & 0 & $0 \%$ & 2 & $100 \%$ \\
\hline 6 & JAAI & 2 & $100 \%$ & 0 & $0 \%$ & 2 & $100 \%$ \\
\hline 7 & VENTURA & 4 & $80 \%$ & 1 & $20 \%$ & 5 & $100 \%$ \\
\hline \multirow[t]{2}{*}{8} & TIAR & 4 & $100 \%$ & 0 & $0 \%$ & 4 & $100 \%$ \\
\hline & Total & 22 & $71 \%$ & 9 & $29 \%$ & 31 & $100 \%$ \\
\hline
\end{tabular}

Table 8. Journal Characteristics-Method Based Journal (2)

\begin{tabular}{|c|c|c|c|c|c|c|c|c|c|c|c|}
\hline \multirow{3}{*}{ No. } & \multirow{3}{*}{ Jurnal } & \multicolumn{10}{|c|}{$2008-2017$} \\
\hline & & \multicolumn{2}{|c|}{ Archival } & \multicolumn{2}{|c|}{ Experiment } & \multicolumn{2}{|c|}{$\begin{array}{l}\text { Literatur } \\
\text { Rivew }\end{array}$} & \multicolumn{2}{|c|}{ Survey } & \multicolumn{2}{|c|}{ Total } \\
\hline & & Sum & $\%$ & Sum & $\%$ & Sum & $\%$ & Sum & $\%$ & Sum & $\%$ \\
\hline 1 & Binus Bisnis Review & 3 & $33 \%$ & 0 & $0 \%$ & 5 & $56 \%$ & 1 & $11 \%$ & 9 & $100 \%$ \\
\hline 2 & JAKI & 3 & $75 \%$ & 0 & $0 \%$ & 0 & $0 \%$ & 1 & $25 \%$ & 4 & $100 \%$ \\
\hline 3 & JAMAL & 4 & $100 \%$ & 0 & $0 \%$ & 0 & $0 \%$ & 0 & $0 \%$ & 4 & $100 \%$ \\
\hline 4 & JKP & 1 & $100 \%$ & 0 & $0 \%$ & 0 & $0 \%$ & 0 & $0 \%$ & 1 & $100 \%$ \\
\hline 5 & JAK & 2 & $100 \%$ & 0 & $0 \%$ & 0 & $0 \%$ & 0 & $0 \%$ & 2 & $100 \%$ \\
\hline 6 & JAAI & 2 & $100 \%$ & 0 & $0 \%$ & 0 & $0 \%$ & 0 & $0 \%$ & 2 & $100 \%$ \\
\hline 7 & VENTURA & 2 & $40 \%$ & 1 & $20 \%$ & 0 & $0 \%$ & 2 & $40 \%$ & 5 & $100 \%$ \\
\hline \multirow[t]{2}{*}{8} & TIAR & 4 & $100 \%$ & 0 & $0 \%$ & 0 & $0 \%$ & 0 & $0 \%$ & 4 & $100 \%$ \\
\hline & Total & 21 & $68 \%$ & 1 & $3 \%$ & 5 & $16 \%$ & 4 & $13 \%$ & 31 & $100 \%$ \\
\hline
\end{tabular}

\section{Prediction of IFRS Research}

Table 9 panel 1 is a tabulation of data that show the topic of earnings management in IFRS research. Five of six IFRS's research-related earnings management studies use discretionary accrual proxies, while only one of them uses cash flow proxies because the article examines real earnings management. IFRS research on the topic of earnings management found using sample companies listing on the Indonesian stock exchanges in year 2008-2014 period, thus it can be concluded that these studies were conducted in the early phase of IFRS adoption in Indonesia. The study still shows the variability results. Three of six studies indicate that there is no difference in earnings management before and after the adoption of IFRS (Dewi \& Ahmar, 2015; Karyada \& Irwanto, 2017; Kusumaningwedari \& Oktorina, 2017) while three other studies found IFRS adoption had an effect on the level of earnings management (Hendika \& Hudiwinarsih, 2014; Sulhani \& Darisman, 2015; Widyawati \& Anggraita, 2013). The difference in outcomes may be due to the research being undertaken in the early stages of the IFRS adoption so that there are still companies that have not implemented IFRS in their accounting policies. As a result, they have not been able to illustrate fully the impact of IFRS adoption on the financial statement quality. Referring to the results of the above analysis of the topic of earnings management in IFRS research, there is still many topics needs to be further investigated, considering that Indonesia is now in the advance adoption of IFRS, and IFRS has been mandatory applied by companies listing on the Indonesian stock exchange since early 2012.

Table 9 panel 2 show IFRS research with relevance topic. From the seven articles that examined IFRS adoption and the relevance of accounting information, there is only one article use ERC proxy for relevance value of information (Arieftiara \& Yanthi, 2017), while the six articles use the price model as a proxy of relevance (Cahyonowati \& Ratmono, 2012; Edvandini, Subroto, \& Saraswati, 2014; Mayangsari, 2010; Pertiwi \& Suhardianto, 2015; Suprihatin \& Tresnaningsih, 2013; Wulandari \& Adiati, 2015). Those articles use years of observation in year 2004-2013. Therefore, it can be concluded that the study was conducted in the early phase of IFRS adoption in Indonesia. The results also still show variability, although only one study did not show a consistence result. Thus, the topic of relevance is still an open topic for further investigation, using the sample year 
in the advance adoption period. In addition, further research can use the Earning Response Coefficient (ERC) proxy to measure the relevance level of accounting information since this proxy is still rarely use in the study as only one of the 31 articles use that proxy.

Table 9. Articles Classification by Topics

Panel 1. Earning Management Topics in IFRS Research

\begin{tabular}{|c|c|c|c|c|}
\hline No. & Title & Proxi & Sample Year & Result \\
\hline 1 & $\begin{array}{l}\text { Kualitas Informasi Akuntansi Pada } \\
\text { Tahap Konvergensi International } \\
\text { Financial Reporting Standard }\end{array}$ & $\begin{array}{l}\text { Income Smoothing \& } \\
\text { Absolut Discretionary } \\
\text { Accrual }\end{array}$ & $\begin{array}{l}2008-2010 \\
2012-2014\end{array}$ & $\begin{array}{l}\text { There is no discretionary accrual } \\
\text { difference between the period } \\
2008-2010 \text { and 2012-2014 }\end{array}$ \\
\hline 2 & $\begin{array}{l}\text { The Effect Of Ifrs Implementation on } \\
\text { Earnings Quality and Corporate Value } \\
\text { (An Empirical Study on Go Public } \\
\text { Manufacturing Companies) }\end{array}$ & $\begin{array}{l}\text { Discretionary } \\
\text { Accrual }\end{array}$ & 2009-2011 & $\begin{array}{l}\text { There is a difference in earnings } \\
\text { quality after IFRS adoption }\end{array}$ \\
\hline 3 & $\begin{array}{l}\text { Pengaruh Konvergensi, Kompleksitas } \\
\text { Akuntansi, dan Probabilitas } \\
\text { Kebangkrutan Terhadap, Timeliness } \\
\text { dan Manajemen Laba }\end{array}$ & Discretionary Accrual & 2010-2011 & $\begin{array}{l}\text { IFRS has a significant negative } \\
\text { effect on earnings management }\end{array}$ \\
\hline 4 & $\begin{array}{l}\text { Does Ifrs Have Impact On Earning's } \\
\text { Quality and Audit Fee? }\end{array}$ & $\begin{array}{l}\text { Absolut Discretionary } \\
\text { Accrual }\end{array}$ & 2010-2014 & $\begin{array}{l}\text { IFRS adoption has no effect on } \\
\text { earnings quality }\end{array}$ \\
\hline 5 & $\begin{array}{l}\text { The Comparative Analysis of } \\
\text { Discretionary Accruals Viewed From } \\
\text { The Styles of Audit and Ifrs Adoption }\end{array}$ & Discretionary Accrual & $\begin{array}{l}2010-2011 \\
2012-2013\end{array}$ & $\begin{array}{l}\text { There is a difference of } \\
\text { discretionary accrual value before } \\
\text { san after the adoption of IFRS }\end{array}$ \\
\hline 6 & $\begin{array}{l}\text { Real Earnings Management of } \\
\text { Operation Before and After The } \\
\text { Implementation of Ifrs Using Cash } \\
\text { Flow Measurement Approach }\end{array}$ & Cash Flow & $\begin{array}{l}2011 \text { dan } \\
2013\end{array}$ & $\begin{array}{l}\text { No difference Real earnings } \\
\text { management before and after IFRS } \\
\text { adoption }\end{array}$ \\
\hline
\end{tabular}

Panel 2. Relevance Topics in IFRS Research

\begin{tabular}{|c|c|c|c|c|}
\hline No. & Title & Proxi & Sample Year & Result \\
\hline 1 & $\begin{array}{l}\text { The Ifrs Adoption: Contribution To } \\
\text { Valuation Theory }\end{array}$ & Price Model & $2004-2008$ & $\begin{array}{l}\text { IFRS adjustments affect the stock } \\
\text { price so that IFRS increases the } \\
\text { firm value relevance }\end{array}$ \\
\hline 2 & $\begin{array}{l}\text { Dampak Konvergensi International } \\
\text { Financial Reporting Standards Terhadap } \\
\text { Nilai Relevan Informasi Akuntansi }\end{array}$ & Price Model & $\begin{array}{l}2006-2007 \\
2008-2009 \\
2010-2011\end{array}$ & $\begin{array}{l}\text { IFRS is proven to empirically } \\
\text { improve the relevance of financial } \\
\text { statements }\end{array}$ \\
\hline 3 & $\begin{array}{l}\text { Perubahan Relevansi Nilai Dalam } \\
\text { Informasi Akuntansi Setelah Adopsi IFRS }\end{array}$ & Price Model & 2007 and 2012 & $\begin{array}{l}\text { Changes in Relevance Before and } \\
\text { After Adoption of Ifrs }\end{array}$ \\
\hline 4 & $\begin{array}{l}\text { Telaah Kualitas Informasi Laporan } \\
\text { Keuangan dan Asimetri Informasi } \\
\text { Sebelum dan Setelah Adopsi IFRS }\end{array}$ & Price Model & 2008 dan 2012 & $\begin{array}{l}\text { There is Improved Relevance After } \\
\text { Adoption of IFRS }\end{array}$ \\
\hline 5 & $\begin{array}{l}\text { Adopsi IFRS dan Relevansi Nilai } \\
\text { Informasi Akuntansi }\end{array}$ & Price Model & $2008-2011$ & $\begin{array}{l}\text { No Improved Relevance of Value } \\
\text { After Adoption of Ifrs }\end{array}$ \\
\hline 6 & $\begin{array}{l}\text { Relevansi Nilai Selisih Loans Book Value } \\
\text { dan Loans Fair Value, Book Value Per } \\
\text { Share, Earnings Per Share dan Ukuran } \\
\text { Perusahaan }\end{array}$ & Price Model & 2010-2013 & $\begin{array}{l}\text { The difference between the book } \\
\text { value and fair value, book value per } \\
\text { share, earnings per share and } \\
\text { company size can be used to } \\
\text { predict the banking stock price }\end{array}$ \\
\hline 7 & $\begin{array}{l}\text { Dampak Konvergensi International } \\
\text { Financial Reporting Standards Terhadap } \\
\text { Nilai Relevan Informasi Akuntansi }\end{array}$ & ERC & 2010-2013 & $\begin{array}{l}\text { There is an increase in ERC for } \\
\text { companies that conduct foreign } \\
\text { currency translation after PSAK No. } \\
10 \text { (Revised 2010) }\end{array}$ \\
\hline
\end{tabular}




\section{Mapping Cause-Effect Relationships}

From the twelve articles about the financial statements quality, we find four articles that describe the cause-effect relationship (Karyada \& Irwanto, 2017; Kusumaningwedari \& Oktorina, 2017; Suprihatin \& Tresnaningsih, 2013; Widyawati \& Anggraita, 2013). According to the Luft and Shields (2007) cause effect relationships are grouped into six models: additive, intervening variable, independent-variable interaction, moderator-variable interaction, cyclical recursive and reciprocal non recursive. Based on grouping the cause-effect relationship by Luft and Shields (2007), we find that one from four articles are found using the moderator-variable interaction model (Suprihatin \& Tresnaningsih, 2013) and other articles using the additive model. From the analysis of the cause-effect relationship, we developed map of IFRS topics that have been done in Indonesia. The mapping process is shown in Figure 1. The result of mapping shows that IFRS research with the theme quality of financial statements with earnings management as a proxy is still needs to be studied. This can be seen from the results of research that is still not consistent. The inconsistency of the results of this study may be due to different research periods or theoretical differences use.

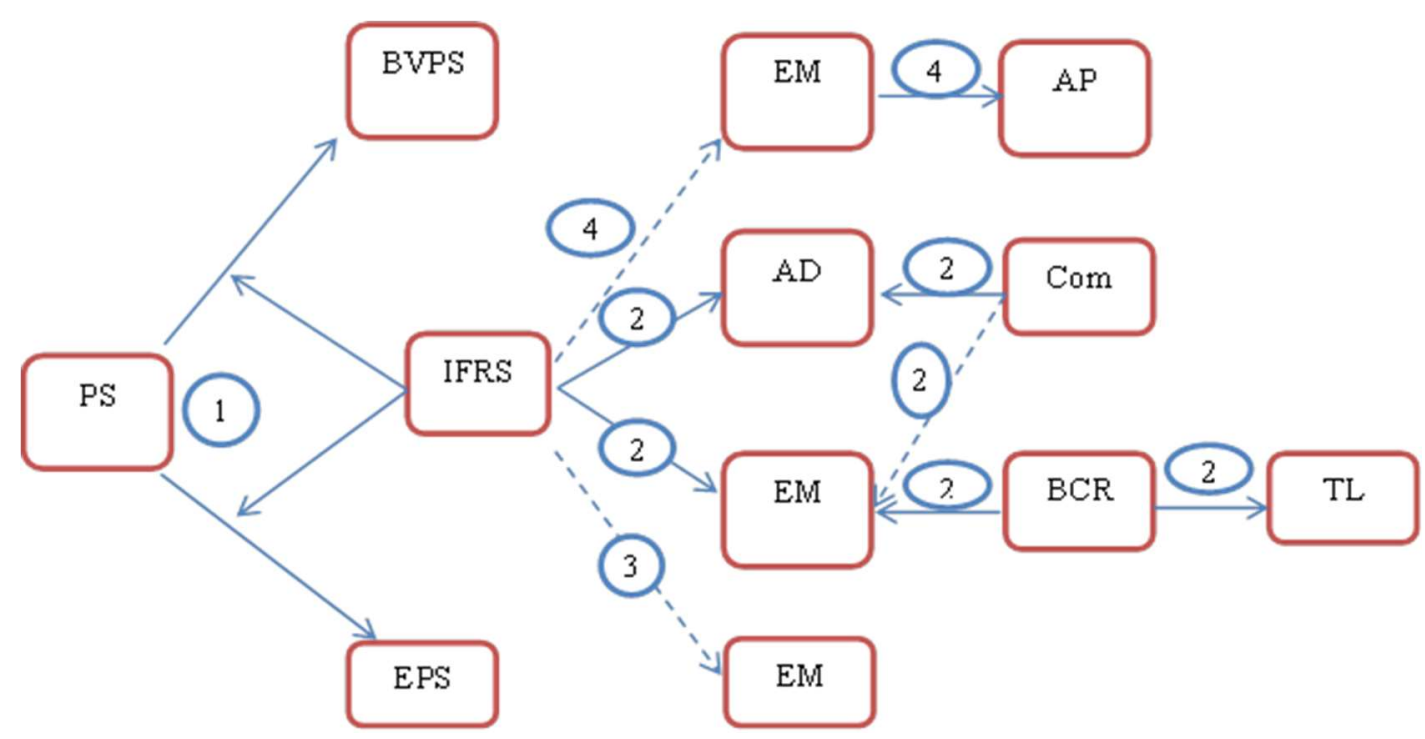

Figure 1. Mapping Cause-Effect Relationships

PS : Price Share

BVPS : Book Value Per Share

EPS : Earning Per Share

IFRS : International Financial Reportinf Standard

EM : Earning Management

$\mathrm{AD}:$ : Audit Delay

AP : Audit Frice

BCR : Bankcrupcy

TL : Timeliness

Com : Complexity
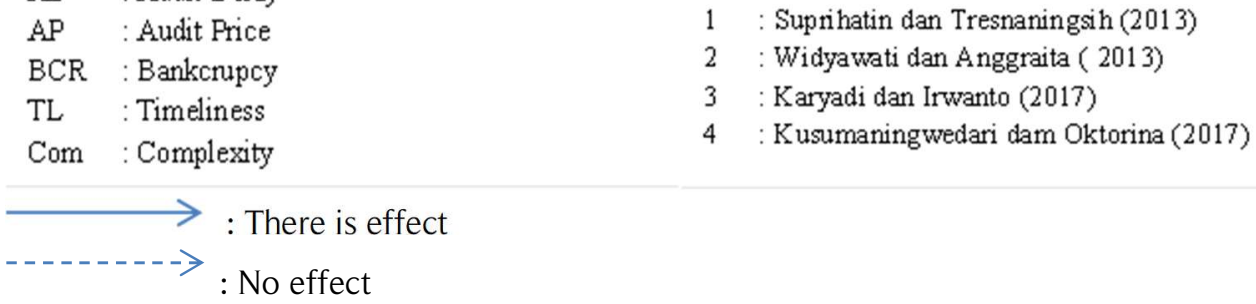

\section{Conclusion}

This study analyzes thirty-one articles of IFRS that are available online from eight national accredited journals. This study takes a sample of IFRS articles from years 2008-2017, classified into topic and method. Most of the articles on IFRS are published in the journal Binus Business Review. The IFRS research trends over the last decade show the topics most frequently discussed are the quality of financial statements. Quantitative methods are the most widely used methods. In addition, archival method is the most dominant method of IFRS research during the past year. 
The topic quality of financial statements is a theme often associated with IFRS research (Suharni \& Yudawijaya, 2016). However, the results of IFRS research published in accredited national journals over the past decade still show inconsistent results. This difference is caused perhaps by different research periods e.g. research conducted prior to IFRS adoption and research conducted on first stage IFRS adoption will certainly find different results. Different theoretical base selection can also result in differences in the outcomes. In addition, differences in sample selection can also lead to differences in research results. By looking at all these differences, IFRS research that is associated with the quality of financial statements is still open for further investigation.

This study has several implications. Firstly, these studies give an overview of IFRS research that has been done for the last ten years. Secondly, it shows the IFRS future research, such as: the impact of IFRS adoption on earnings management. Referring to the research of Suprianto and Setiawan (2017) which shows the trend of earnings management research in Indonesia which experienced an increase in the period of 2008-2016 which is the period of IFRS adoption in Indonesia, it is possible that this increase is influenced by the adoption of IFRS. The relevance topics of accounting information are also still possible to be examined, for example by using the newly used ERC proxy in an IFRS article during the observation year. In addition, the impact of IFRS adoption on taxation seems to be an interesting topic given the differences in the principles of valuation of assets by tax and IFRS. These three studies may be useful for researchers who will conduct IFRS-themed research, taking into account the frequently used topics and methods for the past decade.

This study has several limitations. First, this study only uses accredited national journals samples that are available online, so the articles obtained are still very limited. In addition, the journal which has the publishing period of articles after December 2017 also affects the number of articles obtained because, when we did the observation there are abstract available only. For further research it may not only use articles from accredited national journals but may also consider SINTA indexed journals, for more articles to be found. According technical guidelines for the regulation of Ministry of Research and Higher Education No. 20 Year 2017, accredited national journals are national journals accredited by the Ministry of Research, Technology, and Higher Education, while SINTA indexed journals in the rank Q1-Q6 are equivalent to accredited national journals. Second, these studies only analyze the articles by topic and method. Further research can add analysis the research theory, because the difference of research result may be caused by theory used.

\section{References}

Adhikari, A., Tondkar, R. H., \& Hora, J. A. (2002). An analysis of international accounting research in Journal of International Accounting Auditing \& Taxation: 1992 - 2001. Journal of International Accounting, Auditing \& Taxation, 11, 39-49.

Agoglia, C. P., Doupnik, T. S., \& Tsakumis, G. T. (2011). Accounting standards: the influence of strength on financial reporting decisions. The Accounting Review, 86(3), 747-767. https://doi.org/10.2308/accr.00000045

Arieftiara, D., \& Yanthi, M. D. (2017). Dampak penerapan PSAK 10 (revisi 2010) mengenai pengaruh perubahan kurs valuta asing terhadap daya informatif laba. Jurnal Akuntansi dan Keuangan Indonesia, 14(1), 62-74. http://dx.doi.org/10.21002/jaki.2017.04

Ariyanto, S., Sukendar, H., \& Kurniawati, H. (2012). Penerapan PSAK adopsi IAS 41 agriculture tinjauan pustaka. Binus Business Review, 5(9), 186-193.

Barth, M. E. (2008). Global financial reporting : implications for U.S. Academics. The Accounting Review, 83(5), 1159-1179. https://doi.org/10.2308/accr.2008.83.5.1159

Cahyonowati, N. (2012). Studi eksploratori hubungan antara konvergensi IFRS dengan biaya audit. Jurnal Akuntansi dan Auditing Indonesia, 16(2), 175-184.

Dewi, T. P., \& Ahmar, N. (2015). Real earnings management of operation before and after the implementation of IFRS using cash flow measurement approach. The Indonesian Accounting Review, 5(1), 55-62. https://doi.org/10.14414/tiar.15.050106

Dykxhoorn, H. J., \& Sinning, K. E. (2010). The review and analysis of international accounting research in JIAAT: 2002-2010. Journal of International Accounting, Auditing and Taxation, 19(2), 137-153. https://doi.org/10.1016/j.intaccaudtax.2010.07.005

Efferin, S., \& Rudiawarni, F. (2014). Memahami perilaku stakeholders Indonesia dalam adopsi IFRS: Tinjauan aspek kepentingan, bahasa dan budaya. Jurnal Akuntansi dan Auditing Indonesia, 11(2), 138-164.

Edvandini, L., Subroto, B., Saraswati, E. (2014). Telaah kualitas informasi laporan keuangan dan asimetri informasi sebelum dan setelah adopsi IFRS. Jurnal Akuntansi Multiparadigma, 5(1), 88-95. http://dx.doi.org/10.18202/jamal.2014.04.5008

Evans, L., Gebhardt, G., Hoogendoorn, M., Marton, J., Di Pietra, R., Mora, A., ... Wagenhofer, A. (2005). Problems 
and opportunities of an international financial reporting standard for small and medium-sized entities. The EAA FRSC's comment on the IASB's discussion Paper. Accounting in Europe, 2(1), 23-45. https://doi.org/10.1080/09638180500378949

Hendika, F., \& Hudiwinarsih, G. (2014). The Effect of IFRS implementation on earnings quality and corporate value (an empirical study on go public manufacturing companies). The Indonesian Accounting Review, 4(1), 6570. https://doi.org/10.14414/tiar.14.040107

Herawati, N., \& Bandi, B. (2017). Dua puluh tahun riset perpajakan dalam akuntansi : Suatu studi bibliografi. Jurnal Akuntansi dan Keuangan, 19(2), 102-121. https://doi.org/10.9744/jak.19.2.102-121

Hesford, J. W., Lee, S. S., Stede, W. A. Van Der, \& Young, S. M. (2007). Management Accounting : A Bibliographic Study. In C. S. Chapman, A. G. Hopwood, \& M. D. Shields (Eds.), Handbook of Management Accounting Research (1st ed., pp. 3-26). London. https://doi.org/10.1016/S1751-3243(06)01001-7

Houqe, M. N., Monem, R. M., Tareq, M., \& Zijl, T. Van. (2016). Secrecy and the impact of mandatory IFRS adoption on earnings quality in Europe. Pacific-Basin Finance Journal, 40, 476-490. https://doi.org/10.1016/j.pacfin.2016.08.002

IFRS Foundation. (2018). Use of IFRS Standards around the world 2018. London.

Jeanjean, T., \& Stolowy, H. (2008). Do accounting standards matter? An exploratory analysis of earnings management before and after IFRS adoption. Journal of Accounting and Public Policy, 27(6), 480-494. https://doi.org/10.1016/j.jaccpubpol.2008.09.008

Karyada, I. P. F., \& Irwanto, A. (2017). Kualitas informasi akuntansi pada tahap konvergensi. Jurnal Akuntansi Multiparadigma, 8(2), 308-318.

Kurniawati, H. (2013). Analisis dan tren penggunaan accounting choice yang dilakukan perusahaan di Indonesia studi pustaka. Binus Business Review, 4(2), 765-775.

Kusumaningwedari, L., \& Oktorina, M. (2017). Does IFRS have impact on earning's quality and audit Fee ? Jurnal Akuntansi Multiparadigma, 8(2), 416-426.

Luft, J., \& Shields, M. D. (2007). Mapping management accounting: graphics and guidelines for theory-consistent empirical research. (C. S. Chapman, A. G. Hopwood, \& M. D. Shields, Eds.), Handbook of Management Accounting Research. https://doi.org/10.1016/S1751-3243(06)01002-9

Margaret, \& Hidayat, T. (2016). Persepsi investor terhadap perubahan penyajian Kepentingan Nonpengendali sebelum dan sesudah berlaku efektifnya PSAK 4 (Revisi 2009). Jurnal Akuntansi Dan Keuangan Indonesia, 13(1), 86-101.

Margaretta, S., \& Soepriyanto, G. (2012). Penerapan IFRS dan pengaruhnya terhadap keterlambatan penyampaian laporan keuangan: Studi empiris perusahana manufaktur di Bursa Efek Indonesia periode tahun 20082010. Binus Business Review, 3(2), 993-1009.

Mayangsari, S. (2010). The IFRS adoption: contribution to valuation theory. Journal of Economics, Business and Accountancy Ventura, 13(3), 269-280.

Novianti, E. (2011). Revaluasi inventory dengan menu standard aada SAP-B1 sesuaikah dengan IFRS. Binus Business Review, 2(9), 518-526.

Panggabean, R. (2010). Mengukur tingkat kesesuaian antara standar akuntansi keuangan dengan international financial reporting standards per 1 Januari 2008. Binus Business Review, 1(1), 87-103.

Pertiwi, D., \& Suhardianto, N. (2015). Relevansi nilai selisih loans book value dan loans fair value, book value per share, earnings per share dan ukuran perusahaan. Jurnal Akuntansi dan Keuangan, 17(2), 82-90.

Pranata, D., \& Pujiati, D. (2015). The effect of liquidity, profitability, sales growth , and dividend policy on stock prices after the implementation of IFRS. The Indonesian Accounting Review, 5(2), 169-178. https://doi.org/10.14414/tiar.v5i2.559

Putri, N. K., Baridwan, Z., Supriyadi, \& Nahartyo, E. (2012). Experimental test of framing and non-professional investor's decision: Study of risk information in IFRS No . 7. Journal of Economics, Business, and Accountancy Ventura, 15(110), 305-316.

Sanjaya, I. P. S., \& Barus, M. H. B. (2017). The differences cost of equity capital between before and after adoption of IFRS. Jurnal Keuangan Dan Perbankan, 21(040), 609-620.

Sari, Y. A. N., \& Murni, N. S. I. M. (2016). Analysis of the effect of third party fund, capital adequacy ratio , and loan to deposit ratio on bank's profitability after the application of IFRS. The Indonesian Accounting Review, 6(1), 81-90. https://doi.org/10.14414/tiar.v6i1.577

Shobriati, I., \& Siregar, S. V. (2016). Pengaruh tingkat adopsi IFRS dan proteksi investor terhadap persistensi laba : Analisis lintas negara emerging markets. Jurnal Manajemen Teknologi, 15(3), 324-344.

Shonhadji, N. (2012). Factors of auditor's readiness in implementing IFRS in Indonesia. Journal of Economics, Business, and Accountancy Ventura, 15(110), 133-144. 
Suharni, S., \& Yudawijaya, Y. (2016). Prediksi Riset Ifrs Ditinjau dari Sisi Value of Relevance. Jurnal Ilmu Ekonomi, Manajemen, Dan Akutansi, 5(1), 70-77.

Sukendar, H. (2012). Konsep nilai wajar (fair value) dalam Standar akuntansi berbasis IFRS di Indonesia apa dan bagaimana? Binus Business Review, 3(1), 93-106.

Sukendar, H. (2014). Harmonisasi SAK dan aturan pajak : Mungkinkah ? Binus Business Review, 5(9), 578-587.

Sulhani, S., \& Darisman, H. (2015). The Comparative Analysis of Discretionary Accruals Viewed from The Styles of Audit and IFRS Adoption. Journal of Economics, Business, and Accountancy Ventura, 18(3), 439-447. https://doi.org/10.14414/jebav.v18i3.513

Sun, Y., Steelyana, E., \& Cahyadi, Y. (2014). Market reaction to the adoption of international financial reporting standard in Indonesia. Binus Business Review, 5(2), 466-472.

Suprianto, E., \& Setiawan, D. (2017). Manajemen laba di Indonesia : Studi sebuah bibliografi. Jurnal Keuangan Dan Perbankan, 21(040), 287-301.

Suprihatin, S., \& Tresnaningsih, E. (2013). Dampak konvergensi international financial reporting standards terhadap nilai relevan informasi akuntansi. Jurnal Akuntansi Dan Keuangan Indonesia, 10(2), 171-183.

Villas, M. V., Macedo-Soares, T. D. L. van A. de, \& Russo, G. M. (2008). Bibliographical research method for business administration studies: A model based on scientific journal ranking. Brazilizn Administration Review, 5(June), 139-159.

Wan Ismail, W. A., Kamarudin, K. A., Zijl, T. van, \& Dustan, K. (2013). Earnings quality and the adoption of IFRSbased accounting standards. Asian Review of Accounting, 21(1), 53-73. https://doi.org/10.1108/13217341311316940

Widyawati, A. A., \& Anggraita, V. (2013). Pengaruh konvergensi, kompleksitas akuntansi, dan probabilitas kebangkrutan terhadap timeliness dan manajemen laba. Jurnal Akuntansi Dan Auditing Indonesia, 17(2), $135-155$.

Wulandari, T. R., \& Adiati, A. K. (2015). Perubahan relevansi nilai dalam informasi akuntansi setelah adopsi IFRS. Jurnal Akuntansi Multiparadigma, 6(3), 412-420. https://doi.org/10.18202/jamal.2015.12.6033

Yaacob, N., \& Che- Ahmad, A. (2012). Audit fees after IFRS adoption: Evidence from Malaysia. Eurasian Business Review, 2(1), 31-46.

Zeghal, D., Chtourou, S. M., \& Fourati, Y. M. (2012). The effect of mandatory adoption of IFRS on earnings uality: Evidence from the European Union. Journal of International Accounting Research, 11(2), 1-25. https://doi.org/10.2308/jiar-10221

Zoogah, D. B., \& Rigg, J. S. (2014). Advancing research methodology in the african context : Techniques, methods ,and designs article information. Research Methodology in Strategy and Management, 8, 189-213. 


\section{Appendix}

\begin{tabular}{|c|c|c|c|}
\hline No & Name of Journals & Title & Authors \\
\hline 1 & Binus Bisnis Review & $\begin{array}{l}\text { Mengukur Tingkat Kesesuaian Antara Standar Akuntansi Keuangan Dengan } \\
\text { International Financial Reporting Standards Per } 1 \text { Januari } 2008\end{array}$ & $\begin{array}{l}\text { Pangabean, Rosita } \\
\text { (2010) }\end{array}$ \\
\hline 2 & Binus Bisnis Review & Revaluasi Inventory dengan Menu Standard Pada Sap-B1 Sesuaikah Dengan IFRS & Novianti, Eka (2011) \\
\hline 3 & Binus Bisnis Review & Evaluasi Kurikulum Sekolah Menengah Jurusan Akuntansi Menjelang IFRS & $\begin{array}{c}\text { Deviarti \& } \\
\text { Kurniawati (2012) }\end{array}$ \\
\hline 4 & Binus Bisnis Review & $\begin{array}{l}\text { Penerapan Ifrs dan Pengaruhnya Terhadap Keterlambatan Penyampaian Laporan } \\
\text { Keuangan: Studi Empiris Perusahana Manufaktur di Bursa Efek Indonesia } \\
\text { Periode Tahun 2008-2010 }\end{array}$ & $\begin{array}{c}\text { Margaretta \& } \\
\text { Soepriyanto (2012) }\end{array}$ \\
\hline 5 & Binus Bisnis Review & $\begin{array}{l}\text { Konsep Nilai Wajar (Fair Value) dalam Standar Akuntansi Berbasis IFRS di } \\
\text { Indonesia Apa dan Bagaimana? }\end{array}$ & $\begin{array}{l}\text { Sukendar, Heri } \\
\text { (2012) }\end{array}$ \\
\hline 6 & Binus Bisnis Review & $\begin{array}{l}\text { Analisis dan Tren Penggunaan Accounting Choice yang Dilakukan Perusahaan di } \\
\text { Indonesia Pasca Adopsi IFRS }\end{array}$ & $\begin{array}{l}\text { Kurniawati, Heny } \\
\text { (2013) }\end{array}$ \\
\hline 7 & Binus Bisnis Review & $\begin{array}{l}\text { Tinjauan Rencana Adopsi IAS } 41 \text { Pada Perusahaan Agrikultur di Bursa Efek } \\
\text { Indonesia }\end{array}$ & $\begin{array}{l}\text { Ariyanto , Sukendar } \\
\text { \& Kurniawati } \\
\text { (2014) }\end{array}$ \\
\hline 8 & Binus Bisnis Review & Harmonisasi SAK dan Aturan Pajak: Mungkinkah? & $\begin{array}{l}\text { Sukendar, Heri } \\
\text { (2014) }\end{array}$ \\
\hline 9 & Binus Bisnis Review & $\begin{array}{l}\text { Market Reaction to The Adoption of International Financial Reporting Standard in } \\
\text { Indonesia }\end{array}$ & $\begin{array}{l}\text { Sun, steelyana \& } \\
\text { Cahyadi (2014) }\end{array}$ \\
\hline 10 & JAAI & Studi Eksploratori Hubungan Antara Konvergensi Ifrs dengan Biaya Audit & $\begin{array}{l}\text { Cahyonowati, } \\
\text { Nur(2012) }\end{array}$ \\
\hline 11 & JAAI & $\begin{array}{l}\text { Pengaruh Konvergensi, Kompleksitas Akuntansi, dan Probabilitas Kebangkrutan } \\
\text { terhadap Timeliness dan Manajemen Laba }\end{array}$ & $\begin{array}{c}\text { Widyawati } \\
\text { \&Anggraita (2013) }\end{array}$ \\
\hline 12 & JAK & Adopsi Ifrs dan Relevansi Nilai Informasi Akuntansi & $\begin{array}{l}\text { Cahyonowati \& } \\
\text { Ratmono (2012) }\end{array}$ \\
\hline 13 & JAK & $\begin{array}{l}\text { Relevansi Nilai Selisih Loans Book Value dan Loans Fair Value,Book Value Per } \\
\text { Share, Earnings Per Share dan Ukuran Perusahaan }\end{array}$ & $\begin{array}{l}\text { Pertiwi \& } \\
\text { Suhardiyanto (2015) }\end{array}$ \\
\hline 14 & JAKI & $\begin{array}{l}\text { Dampak Konvergensi International Financial Reporting Standards Terhadap Nilai } \\
\text { Relevan Informasi Akuntansi }\end{array}$ & $\begin{array}{c}\text { Suprihatin \& } \\
\text { Tresnaningsih (2013) }\end{array}$ \\
\hline 15 & JAKI & $\begin{array}{l}\text { Memahami Perilaku Stakeholders Indonesia dalam Adopsi Ifrs: Tinjauan Aspek } \\
\text { Kepentingan, Bahasa,dan Budaya }\end{array}$ & $\begin{array}{c}\text { Efferin \& } \\
\text { Rudiawarni (2014) }\end{array}$ \\
\hline 16 & JAKI & $\begin{array}{l}\text { Persepsi Investor Terhadap Perubahan Penyajian Kepentingan Nonpengendali } \\
\text { Sebelum dan Sesudah Berlaku Efektifnya Psak } 4 \text { (Revisi 2009) }\end{array}$ & $\begin{array}{l}\text { Margaret \& Hidayat } \\
\quad(2016)\end{array}$ \\
\hline 17 & JAKI & $\begin{array}{l}\text { Dampak Penerapan Psak } 10 \text { (Revisi 2010) Mengenai Pengaruh Perubahan Kurs } \\
\text { Valuta Asing Terhadap Daya Informatif Laba }\end{array}$ & $\begin{array}{l}\text { Arieftiara \& Yanthi } \\
\qquad(2017)\end{array}$ \\
\hline 18 & JKP & The Differences Cost of Equity Capital between Before and After Adoption of IFRS & $\begin{array}{l}\text { Sanjaya \& Barus } \\
\text { (2017) }\end{array}$ \\
\hline 19 & JAMAL & $\begin{array}{l}\text { Telaah Kualitas Informasi Laporan Keuangan dan Asimetri Informasi Sebelum dan } \\
\text { Setelah Adopsi Ifrs }\end{array}$ & $\begin{array}{l}\text { Edvandini, Subroto } \\
\text { \& Saraswati (2014) }\end{array}$ \\
\hline 20 & JAMAL & Perubahan Relevansi Nilai dalam Informasi Akuntansi Setelah Adopsi Ifrs & $\begin{array}{l}\text { Wulandari \& } \\
\text { Adiwati (2015) }\end{array}$ \\
\hline 21 & JAMAL & $\begin{array}{l}\text { Kualitas Informasi Akuntansi pada Tahap Konvergensi International Financial } \\
\text { Reporting Standard }\end{array}$ & $\begin{array}{l}\text { Karyada \& Irwanto } \\
\qquad(2017)\end{array}$ \\
\hline 22 & JAMAL & Does Ifrs Have Impact on Earning's Quality and Audit Fee? & $\begin{array}{l}\text { Wedari \& Oktorina } \\
\qquad \text { (2017) }\end{array}$ \\
\hline 23 & VENTURA & The Ifrs Adoption: Contribution to Valuation Theory & $\begin{array}{l}\text { Mayangsari, Sekar } \\
\quad(2010)\end{array}$ \\
\hline 24 & VENTURA & $\begin{array}{l}\text { Experimental Test Of Framing and Non-Professional Investor's Decision: Study of Risk } \\
\text { Information in Ifrs No. } 7\end{array}$ & $\begin{array}{l}\text { Putri, Supriyadi, } \\
\text { Baridwan \& } \\
\text { Nahartyo (2012) }\end{array}$ \\
\hline 25 & VENTURA & Factors Of Auditor's Readiness In Implementing Ifrs In Indonesia & $\begin{array}{l}\text { Shonhadji, Nanang } \\
\text { (2012) }\end{array}$ \\
\hline 26 & VENTURA & Adoption of International Financial Reporting Standards (IFRS) in Indonesia & Hamidah (2013) \\
\hline 27 & VENTURA & $\begin{array}{l}\text { The Comparative Analysis Of Discretionary Accruals Viewed From The Styles Of Audit } \\
\text { and IFRS Adoption }\end{array}$ & $\begin{array}{l}\text { Sulhani \& Darisman } \\
\qquad(2015)\end{array}$ \\
\hline 28 & TIAR & $\begin{array}{l}\text { The Effect of IFRS Implementation on Earnings Quality and Corporate Value (an } \\
\text { Empirical Study on Go Public Manufacturing Companies) }\end{array}$ & $\begin{array}{c}\text { Hendika \& } \\
\text { Hudiwinarsih (2014) }\end{array}$ \\
\hline 29 & TIAR & $\begin{array}{l}\text { The Effect of Liquidity, Profitability, Sales Growth, and Dividend Policy on Stock Prices } \\
\text { After the Implementation of IFRS }\end{array}$ & $\begin{array}{l}\text { Pranata \& Pujiati } \\
\qquad(2015)\end{array}$ \\
\hline 30 & TIAR & $\begin{array}{l}\text { Real Earnings Management of Operation Before and After the Implementation of IFRS } \\
\text { Using Cash Flow Measurement Approach }\end{array}$ & $\begin{array}{l}\text { Dewi \& Ahmar } \\
\quad(2015)\end{array}$ \\
\hline 31 & TIAR & $\begin{array}{l}\text { Analysis of the Effect of Third Party Fund, Capital Adequacy Ratio,and Loan to Deposit } \\
\text { Ratio on Bank"s Profitability After the Application of IFRS }\end{array}$ & $\begin{array}{l}\text { Sari \& Murni } \\
\quad(2016)\end{array}$ \\
\hline
\end{tabular}

